Columbia Law School

Scholarship Archive

\title{
A Better Financing System? The Death - and Possible Rebirth - of the Presidential Nomination Public Financing Program
}

Richard Briffault

Columbia Law School, brfflt@law.columbia.edu

Follow this and additional works at: https://scholarship.law.columbia.edu/faculty_scholarship

Part of the Banking and Finance Law Commons, Election Law Commons, and the Public Law and Legal Theory Commons

\section{Recommended Citation}

Richard Briffault, A Better Financing System? The Death - and Possible Rebirth - of the Presidential Nomination Public Financing Program, The Best Candidate: Presidential Nomination IN Polarized Times, Eugene D. Mazo \& Michael R. Dimino, Eds., Cambridge University Press, 2020; Columbia Public Law RESEARCH PAPER No. 14-645 (2019).

Available at: https://scholarship.law.columbia.edu/faculty_scholarship/2590

This Working Paper is brought to you for free and open access by the Faculty Publications at Scholarship Archive. It has been accepted for inclusion in Faculty Scholarship by an authorized administrator of Scholarship Archive. For more information, please contact scholarshiparchive@law.columbia.edu. 


\title{
A BETTER FINANCING SYSTEM?
}

\author{
The Death - and Possible Rebirth - of the Presidential Nomination \\ Public Financing Program \\ Richard Briffault ${ }^{*}$
}

Forthcoming in

\begin{abstract}
The Best Candidate: Presidential Nomination in Polarized Times (Euaene D. Mazo and Michael R. Dimino, eds., Cambridge Univ. Press 2020).
\end{abstract}

\begin{abstract}
In 1974 Congress authorized public funding for presidential nomination campaigns. Public funding was crucial to Jimmy Carter's nomination in 1976 and to Ronald Reagan's nearly successful campaign the same year, and continued to be an important factor in presidential nomination contests for more than two decades after that. But no major candidate has used the program since 2004. Due the program's built-in limitations, changes in the nomination process, and campaign finance developments, the program is completely irrelevant today.

It has been argued that the program isn't really needed. Although one argument for public funding is that promotes electoral competition the 2008 races in both parties and the 2016 Democratic nomination were hotly contested, and the races for the 2012 and 2016 Republican nominations and the current 2020 Democratic campaign have had record numbers of candidates. A second goal of public funding is to reduce the clout of large donors, but the last several elections have been marked by a sharply increased role for small-dollar donors. Nonetheless, the current private-funding system continues to pose major barriers to entry. Although small donations have grown, the volume of very large donations has grown as well, and big donors, big-donor-funded Super PACs, and wealthy self-funded candidates have a disproportionate role in nomination campaign finance.

This chapter reviews the history of the presidential nomination public funding program, its initial impact and the reasons for its subsequent collapse. It then examines the state and local public funding systems that have drawn the participation of viable candidates, and increased both competitiveness and the role of small donors. Based on the lessons of the failed federal system and the successful state and local ones, it sketches out the reasons for and the elements of a reborn presidential nomination public funding program.
\end{abstract}

\footnotetext{
* Joseph P.Chamberlain Professor of Legislation, Columbia Law School.
} 


\section{Introduction}

In the spring of 1974, the 31-year-old junior Senator from Delaware, Joseph R. Biden, Jr., published a law review article in which he decried the traditional system of privately-financed election campaigns. Private financing, Senator Biden contended, "affords certain wealthy individuals or special interest groups the potential for exerting a disproportionate influence over both the electoral mechanism and the policy-making processes of the government." Moreover, Biden urged, private funding poses an obstacle to the candidacies of "individuals of moderate means" and so was at odds with the "concept of American democracy [that] presumes that all citizens, regardless of access to wealth, have equal access to the political process." In addition, he argued that private funding favored incumbents. ${ }^{1}$ To address the "Political Darwinism" ${ }^{2}$ of private financing, Biden called on Congress to adopt a system of public funding for all federal candidates.

Biden's article grew out of a long tradition of treating public funding as integral to campaign finance regulation. As far back as 1907, President Theodore Roosevelt, in his Seventh Annual Message to Congress, had called for public funding of candidates, and in the late 1960s and early 1970s Congress began to take tentative steps in that direction. ${ }^{3}$ Congress created a Presidential Election Campaign Fund, with a mandate initially limited to funding general election candidates. In October 1974, Congress went further and authorized, starting in the 1976 election, the use of public funds to finance the party nominating conventions and the campaigns of the candidates running for their nominations. ${ }^{4}$ The pre-nomination public funding system differs from the general election program, however. The general election system authorizes large flat grants

\footnotetext{
${ }^{1}$ Joseph R. Biden, J., Public Financing of Elections: Legislative Proposals and Constitutional Questions, 69 NW. L. REV. 1, 2-3 (1974).

${ }^{2}$ Id. at 2 .

${ }^{3}$ See Richard Briffault, Reforming Campaign Finance Reform: The Future of Public Financing, in DEMOCRACY BY THE PeOPle: Reforming CAmpaign FinanCe In America 103-04 \& nn. 4-5 (Eugene D. Mazo \& Timothy K. Kuhner, eds., Cambridge U. Press 2018).

${ }^{4}$ See Federal Election Campaign Act Amendments of 1974, Pub. L. 93-443 (Oct. 15, 1974), section 408, creating the Presidential Primary Matching Payment Account, chapter 96 of subtitle H of the Internal Revenue Code, 26 U.S.C. 9031 et seq.
} 
for the major party nominees who agree to limit their spending to the government grant. The pre-nomination program was designed to match small donations, so that even with public funding, candidates would still need and be able to use private contributions, albeit subject to a spending limit.

True to his principles, Senator Biden twice turned to the public funding program when he ran for the Democratic presidential nomination. In the 1987-88 election, he obtained $\$ 901,213$ in federal matching funds, which were added to the $\$ 3.8$ million in private contributions he received in his short-lived campaign. Counting loans and transfers from his other campaign committees, public funds accounted for about $22.3 \%$ of Biden's total campaign spending. ${ }^{5}$ When Biden ran again in 2007-08, he collected $\$ 2,033,471.83$ in public funds, compared to less than $\$ 8.6$ million in private individual contributions to his campaign. With transfers and loans factored in, public funds accounted for about 14\% of Biden's 2008 campaign spending. ${ }^{6}$ Biden's 2008 campaign also ended early, with him dropping out after placing fifth in the lowa caucuses held on January 3, 2008.

Biden's 2020 campaign for the Democratic presidential nomination, however, is not using public funds. Instead, the campaign is relying entirely on private contributions, most likely with substantial support from independent committees. In relying entirely on private funding this time, Biden is not alone. Every single one of the nearly two dozen Democratic candidates is entirely financed by private contributions. Nor is the absence of public funding in the 2020 race unusual. In 2016, exactly one of the 23 major party primary contenders - across both parties - took public funds, with both of the major party nomination winners - Donald Trump and Hillary Clinton wholly privately funded. So, too, both major party nominees in 2012 - Barack Obama and Mitt Romney - and all the other 2012 contenders financed their nomination campaigns from private funds; so did both major party nomination winners and the runners-up in 2008. Indeed, the last Democratic candidate who used public funds in

\footnotetext{
${ }^{5}$ Biden, Joseph, R. Jr., Financial Summary (1988), Federal ELECTION COMMISSION, https://www.fec.gov/data/candidate/P80000722/?cycle=1988\&election full=true.

${ }^{6}$ Biden, Joseph, R. Jr., Financial Summary (2008), FEDERAL ELECTION COMMISSION, https://www.fec.gov/data/candidate/P80000722/?cycle=2008\&election full=true.
} 
winning his party's presidential nomination was Al Gore in 2000, and the last successful publicly-funded candidate for the Republican nomination was Bob Dole in 1996.

It is not as if the public funding program was always a flop. Indeed, public funding was an important factor in major party nomination campaigns in the first quartercentury after the program was adopted. Public funding was critical to the emergence of Jimmy Carter in 1976 and to Ronald Reagan's near-successful 1976 campaign, which helped position him for his successful 1980 run. Public funding has also been credited with shaping and sustaining nomination contests over several decades, by helping to finance the candidates who were the principal challengers to their party's front-runners - George H.W. Bush in 1980, Gary Hart in 1984, Jesse Jackson in 1988, Pat Buchanan in 1992, John McCain in 2000, and John Edwards in $2004 .^{7}$

So, what happened? What caused the collapse of the presidential nomination public funding program, beginning in 2000 and culminating in its complete irrelevance by 2012 ? What have the consequences been for presidential nomination campaigns? Should the presidential nomination public funding program be re-created, and if so, how?

Part II of this chapter reviews the structure and legal framework of the presidential nomination public funding system. It tracks the declining use of public funds over the last two decades, and examines the reasons for the public funding program's collapse.

Part III then considers whether a presidential nomination public funding program should be re-created, and if so, how. Notwithstanding young Senator Biden's concern about the inability of candidates to raise the funds needed to mount competitive campaigns without public funding, both parties in 2008, the Republicans in 2012 , and both parties in 2016 had highly competitive nomination contests, with the 2008 Democratic race and especially the Republican 2016 nomination campaign joined by what were then record numbers of contestants. The 2020 Democratic nomination has

\footnotetext{
7 See Campaign Finance institute Task Force on Financing Presidential Nominations, So the Voters May Choose... ReVIVING the Presidential Matching Fund SyStem 2-4 (2005) (hereinafter “CFI 2005”).
} 
even more entrants than the Republicans did in 2016. Also, many of these candidates managed to receive significant support from low-dollar donors. Nonetheless, most of the truly competitive candidates have been largely dependent on large donors or, like Mitt Romney in 2008 or Donald Trump in 2016, their personal wealth. With the exception of Bernie Sanders in 2016, the candidates who relied primarily on low-dollar donations usually exited their races early.

As a result, there remains a need for public funding to counter the role of large donors and to help sustain the campaigns of outsider candidates. Moreover, the growing experience of many states and cities with forms of public funding that depart from and improve on the failed presidential model provide some guidance as to how to create a workable reformed system.

Part IV will conclude by sketching out the elements necessary for a reinvigorated public funding system.

II. The Presidential Nomination Public Funding Program In Brief

\section{A. Structure}

The presidential nomination public funding program provides qualified candidates with public funds by matching small individual donations. To qualify, a candidate must raise at least $\$ 100,000$, consisting of at least $\$ 5000$ in individual contributions - counting only $\$ 250$ from any individual's donation - from residents of at least twenty states. ${ }^{8}$ These numbers have not been changed since the program's enactment in 1974. The program will then match on a dollar-per-dollar basis each individual contribution the candidate receives, up to $\$ 250$ per donor. The law sets a spending limit - which is adjusted for inflation - as a condition for public funding and also caps the amount of public funds the candidate can receive to half the spending limit. In 2016 the pre-nomination spending limit was $\$ 48.07$ million (although additional funds could be spent for legal, accounting, and fundraising costs), so the maximum grant in 2016 was effectively $\$ 24$ million. By comparison, Democratic nominee Hillary Clinton raised more than $\$ 500$ million for her nomination campaign

${ }^{8} 26$ U.S.C. $\S 9033$ (b) (3), (4). 
in 2016, her runner-up Bernie Sanders raised \$237 million, and Republican nominee Donald Trump raised $\$ 350$ million. Moreover, although the law provides for the matching of any eligible contributions received starting the year before the year of the presidential election, no matching payments can actually be made to a candidate until the start of the year of the presidential election. ${ }^{9}$

The law also limits how much a candidate can spend in each state to $\$ 200,000$, adjusted for inflation, or to a specified inflation-adjusted amount based on the number of voters in each state. ${ }^{10}$ That meant that in 2016 a publicly-funded presidential contender would have been allowed to spend just $\$ 961,400$ in the allimportant New Hampshire primary. ${ }^{11}$ In addition, the law limits a candidate to spending no more than $\$ 50,000$ in personal or immediate family funds. ${ }^{12} \mathrm{~A}$ candidate ceases to be eligible for matching funds thirty days after he or she receives less than ten percent of the vote in two consecutive primaries that the candidate contested, unless he or she rebounds by obtaining twenty percent of the vote in another primary.

The program, along with general election public funding, is funded voluntarily by taxpayers who choose to check-off a box on their tax form that will dedicate a small portion of their tax liability to the Presidential Election Campaign Fund. The check-off was originally $\$ 1$ (or $\$ 2$ for a couple filing a joint tax return) and was raised to $\$ 3$ (and $\$ 6$ for couple filing jointly) in 1993.

As the one-to-one match and the cap on public funds at half the spending limit indicate, the nomination public funding program was intended to be a hybrid of public and private. Candidates need to raise private funds in order to receive public funds, and the program assumes that private funds will constitute a significant portion of campaign treasuries. Public funding was intended to reduce candidate dependence on large donors, but not fully to replace private donations.

B. Constitutional Framework

\footnotetext{
${ }^{9} 26$ U.S.C. § 9032 (6).

${ }^{10} 26$ U.S.C. $\S 9035$.

${ }^{11}$ Presidential Spending Limits for 2016, FedERAL ELECTION COMMISSION, https://transition.fec.gov/pages/brochures/pubfund limits 2016.shtml.

1226 U.S.C. § 9035.
} 
In the foundational case of Buckley v. Valeo, ${ }^{13}$ the Supreme Court sustained both the general election and pre-nomination public funding programs, holding that the public financing of campaigns advances the general welfare goals of reducing "the deleterious influence of large contributions on the political process," "facilitat[ing] communication by candidates with the electorate," and "free[ing] candidates from the rigors of fundraising." 14 The Court went on to find that "public financing as a means of eliminating the influence of large private contributions furthers a significant government interest." ${ }^{15}$ Buckley held that candidates could be required to accept spending limits - which are otherwise unconstitutional -- as a condition for receiving public funds. ${ }^{16}$ The Court also upheld the specific eligibility requirements for obtaining pre-nomination campaign funding and rejected the contention that the matching funds format favors wealthy voters and candidates. ${ }^{17}$

In subsequent cases - which focused on general election presidential public funding, rather than the pre-nomination program - the Court rejected the argument that candidates are somehow coerced into accepting public funds, ${ }^{18}$ but the Court in 1985 also invalidated a provision of the public funding law that limited independent expenditures in support of or opposed to a publicly-funded candidate. ${ }^{19}$ As a result, spending-limited publicly-funded candidates have to contend with both non-spendinglimited privately-funded opponents and non-spending-limited hostile independent committees - although a publicly-funded candidate could also benefit from the unlimited spending of a supportive independent committee.

In 2011, in a case known as Arizona Free Enterprise -- involving a state public funding program - the Court held that the government could not provide a publicly-funded candidate with additional public funds to respond to high levels of spending by a privately-funded opponent or hostile independent committee. ${ }^{20}$ The

\footnotetext{
${ }^{13} 424$ U.S. 1 (1976)

${ }^{14} / d$. at 91.

${ }^{15} / d$. at 97.

${ }^{16} / d$. at 57 n. $65,107-08$.

17 Id. at 105-08.

${ }^{18}$ Republican Nat'I Comm. v. FEC, 445 U.S. 955 (1980), aff'd Republican Nat'। Comm. v. FEC, 487 F.Supp. 280

(S.D.N.Y. 1980).

${ }^{19}$ FEC v. Nat'I Cons. PAC, 470 U.S. 480 (1985).

${ }^{20}$ Arizona Free Enterprise Club's Freedom Club PAC v. Bennett, 564 U.S. 721 (2011).
} 
Court determined that such a "fair fight" or "rescue" mechanism burdens the speech of the candidate or committee whose spending triggered the payment of the additional public funds, and that the burden is not justified by the interests that support public funding. ${ }^{21}$ Although the presidential public funding program does not have such a trigger mechanism, Arizona Free Enterprise limits the ability to make public funding more attractive to candidates and so has important implications for any re-design of the presidential nomination public funding program.

C. History: Rise, Decline, and Fall, 1976-2016

In the first six presidential election cycles after the public financing program was enacted - 1976, 1980, 1984, 1988, 1992, and 1996 - virtually every major presidential contender in both parties participated in the public funding program, and, typically, federal matching funds constituted a significant fraction of their total contributions. In 1976, Jimmy Carter's \$8 million in private individual contributions was matched by $\$ 3.6$ million in public funds. On the Republican side, a third of Gerald Ford's primary receipts and $40 \%$ of Ronald Reagan's funding consisted of public funds. ${ }^{22}$ The funds were particularly valuable at the start of the campaign season to the virtually unknown Jimmy Carter and to Ronald Reagan, who was challenging an incumbent president of his own party, as each had less than $\$ 50,000$ on hand before the public funds began to flow at the beginning of $1976 .{ }^{23}$ Again, in 1980, both for Reagan and his principal opponent George H.W. Bush on the Republican side, and for Carter and his challenger Senator Ted Kennedy on the Democratic side, matching payments accounted for about a third of their total funds. ${ }^{24}$ The payment of public funds at the start of 1980 has been credited with saving Bush from financial elimination and enabling him to become the runner-up to Reagan and Reagan's pick for vice-president. ${ }^{25}$

The pattern continued through the 1984, 1988, and 1992 elections, with both major party nomination winners and their principal opponents taking public

\footnotetext{
${ }^{21}$ Id. at 736-55.

22 Michael J. Malbin \& Brendan Glavin, CFI's Guide to Money in Federal Elections: 2016 in Historical Context, at 27 (Table 1-1) (Camp. Fin. Inst. 2018).

${ }^{23}$ See CFI 2005, supra note 7, at 2.

${ }^{24}$ MALBIN \& GLAVIN, supra note 22, at 27 (Table 1-1).

${ }^{25}$ See CFI 2005, supra note 7, at 3.
} 
funds. ${ }^{26}$ So, too, the infusion of public funds at the start of the election year enabled candidates who were virtually out of cash - Gary Hart (1984), Jesse Jackson (1988), Paul Tsongas (1992), Pat Buchanan (1992) - to keep in their races and mount major challenges against the frontrunners. ${ }^{27}$ In this period, matching funds accounted for a quarter to a third of the war chests of participating candidates. ${ }^{28}$ Things began to change in 1996. President Clinton's Democratic nomination was essentially uncontested, but he still participated in the public funding program, and public funds accounted for almost one-third of his primary period receipts. On the Republican side, however, although the ultimate nomination winner Bob Dole participated in the primary matching program, as did his principal runner-up Pat Buchanan, Dole's other main opponent, millionaire Steve Forbes, opted out of the program and committed nearly $\$ 40$ million of his own funds to his campaign, thereby virtually equaling Dole's combination of private contributions and public funds. ${ }^{29}$ By winning two early primaries and ultimately about $11 \%$ of the primary vote, ${ }^{30}$ Forbes became the first serious primary candidate to opt out of public funding since the program was adopted. ${ }^{31}$

In 2000, the initial crack in the public funding program began to widen, as George W. Bush became the first candidate to win a major party nomination without public funding since the public funding program was enacted. To be sure, public funding enabled John McCain to mount a serious challenge to Bush, ${ }^{32}$ winning seven primaries and $31 \%$ of the Republican primary vote. ${ }^{33}$ But Bush's $\$ 103$ million in

\footnotetext{
${ }^{26}$ MALBIN \& GLAVIN, supra note 22 , at 26 (Table $1-1$ ).

${ }^{27}$ CFI 2005, supra note 7, at 3.

${ }_{28}$ Michael J. Malbin, Small Donors, Large Donors and the Internet: The Case for Public Funding After Obama, CAMPAIGN FINANCE INSTITUTE, at 5 (2009), http://www.cfinst.org/president/pdf/PresidentialWorkingPaper April09.pdf.

${ }^{29} \mathrm{CFI} 2005$, supra note 7, at 25 (Table 1-1).

301996 Republican Party presidential primaries, WIKIPEDIA (last visited May 22, 2019), https://en.wikipedia.org/wiki/1996 Republican Party presidential primaries.

31 In 1980, John Connally, the former Governor of Texas and Secretary of the Treasury, ran for the Republican presidential nomination without taking public funds. Although he spent \$11 million on his campaign, he did not win a single primary and secured the support of only a single delegate. See John Connally, WIKIPEDIA (last visited May 22, 2019), https://en.wikipedia.org/wiki/John Connally.

32 See CFI 2005, supra note 7, at 3

${ }^{33}$ See 2000 Republican Party presidential primaries, WIKIPEDIA (last visited May 22, 2019) https://en.wikipedia.org/wiki/2000 Republican Party presidential primaries.
} 
private primary contributions was more than double McCain's total receipts; indeed, it was more than double the pre-nomination campaign receipts of any major party candidate in the preceding quarter-century. ${ }^{34}$ Although both major Democratic contenders - Al Gore and Bill Bradley -- opted to take matching funds, which accounted for roughly $30 \%$ of their receipts, ${ }^{35}$ the writing was on the wall. In 2004, the winners of both major party nominations - George W. Bush and John Kerry -declined public funding. Each raised well over $\$ 200$ million, or far more than he could have raised if he had chosen to rely on public funding. Again, public funding sustained a number of other Democratic contenders through the early primaries, and public funding arguably enabled John Edwards to become Kerry's longest-lasting opponent, first runner-up, and vice presidential pick. ${ }^{36}$ But 2004 was the last election in which public funding played any significant factor in the party nomination contests.

In 2008, the two leading Democratic contenders - Barack Obama and Hillary Clinton - opted out of public funding, as did all of the principal Republican candidates - John McCain, Mitt Romney, Rudy Giuliani, Rand Paul, and Mike Huckabee. To be sure, a handful of prominent Democratic contenders - John Edwards, Joe Biden, Christopher Dodd, and Dennis Kucinich -- qualified for public funds, but only Edwards came in as high as second in any state primary or caucus contest. With the publicly funded candidates mostly dropping out early, the total allocation of matching funds in 2008 came to just $\$ 20$ million, or less than $2 \%$ of the $\$ 1.2$ billion raised by all of the presidential hopefuls in the nomination phase of that year's election. ${ }^{37}$ In 2012, the public funding program ceased to play any role in the pursuit of the major party nominations. ${ }^{38}$ Matching funds payments dropped to a little more than $\$ 350,000$ in 2012 , with all the funds going to candidates for third party nominations. In 2016, the program played a marginally larger role, with Maryland Governor Martin O'Malley, a candidate for the Democratic nomination, qualifying for

\footnotetext{
${ }^{34}$ See CFI 2018, supra note 22, at 25-27 (Table 1-1).

35 Id. at 25.

${ }^{36}$ See CFI 2005, supra note 7, at 3-4.

37 See John C. Green \& Diana Kingsbury, Financing the 2008 Presidential Nominating Campaigns, in FINANCING THE 2008 EleCtion: AsSESSING RefORM 86, 96-97 (David B. Magleby \& Anthony Corrado eds., Brookings Inst. Press 2011).

${ }^{38}$ See Presidential Campaign Receipts Through December 31, 2012, FEDERAL ELECTION COMmISSION, https://transition.fec.gov/press/summaries/2012/tables/presidential/Pres1 2012 24m.pdf.
} 
public funds, and obtaining a little over $\$ 1$ million in matching funds, or about onesixth of his campaign receipts. O'Malley, however, placed a very distant third-place in the lowa caucuses and dropped out of the race early. By comparison, the two leading Democratic contenders, Hillary Clinton and Bernie Sanders, together raised in excess of $\$ 630$ million in private contributions. ${ }^{39}$ None of the Republican candidates took private funds. ${ }^{40}$

\section{Why Did Public Funding Fail?}

The public funding system failed for two reasons, which are essentially two sides of the same coin: Public funding became incapable of providing candidates with enough money to cover the drastically increased costs of the major party nomination contests, and, conversely, it became much easier to raise the necessary funds from private sources. More fundamentally, public funding fell victim to the interplay of the dramatic changes in the nomination process, developments in the campaign finance system, and public funding's own unchanged rules.

Turning first to the failure of public funding to keep up with the costs of running for a major party nomination, perhaps the most significant development in the four decades since public funding was adopted is the changed nature of the nomination contest itself. In 1972, the last election before public funding was enacted, Democratic candidates contested just 21 primaries and 11 caucuses, ${ }^{41}$ and just $61 \%$ of Democratic convention delegates and $54 \%$ of Republican delegates were chosen in primaries. ${ }^{42}$ By 1976 , the percentage of delegates chosen in primaries had risen to $73 \%$ and $68 \%$, respectively. ${ }^{43}$ Those numbers continued to rise in the 1980 s, so that by 1988 , virtually every jurisdiction

\footnotetext{
${ }^{39}$ See Presidential Table 1: Presidential Pre-Nomination Campaign Receipts Through December 31, 2016, FEDERAL ELECTION COMmission (April 7, 2017), https://transition.fec.gov/press/summaries/2016/tables/presidential/PresCand1 2016 24m.pdf. 2004, in The Election After Reform: Money Politics and the Bipartisan Campaign Reform Act 220 (Michael J. Malbin, ed., Rowman \& Littlefield 2006). 
conducted a primary or caucus and used these contests to select or bind convention delegates.

Not only did the number of state contests rise sharply, but primaries were increasingly frontloaded. In 1972, the New Hampshire primary took place on March 7. In 2004 , it was held on January 27 . In 2008 , it was on January 8 . Moreover, whereas in the 1970 s, primaries were sequenced "at what now seems like a leisurely pace," 44 with major contests often several weeks apart, starting in 1984 and 1988, they began to be bunched together in ever-more "super" Tuesdays. In 2004, there were eighteen contests in February and another ten on March 2, when John Kerry effectively secured the Democratic nomination. ${ }^{45}$ In 2008, there were twenty-three Democratic contests and twenty-one Republican contests on a single day - and a very early day at that, February $5 .{ }^{46}$ Although the Obama-Clinton race continued until late spring, by March 4, 2008, John McCain had effectively triumphed over a crowded Republican field and secured his party's nomination. ${ }^{47}$

The public funding program has become an anachronism. Provisions that worked in the 1970s and 1980s are simply incapable of handling the timing, pace, and intensity of the twenty-first century nomination process. The small size of the grant and the low spending limit were not designed for a system with more than fifty state campaigns (as well as campaigns in the District of Columbia and other jurisdictions that select convention delegates). The prohibition on the payment of funds before January 1 of the election year fails to deal with the early dates of the first contests and their crucial importance in framing the race. The state-specific spending limits make no sense, particularly when lowpopulation (and low-spending limit) states like lowa and New Hampshire loom so large in the nomination calendar. These limits are also fundamentally at odds with the national scope of the Super Tuesday elections.

\footnotetext{
44 Id. at 221.

${ }^{45}$ See John C. Green, Financing the 2004 Presidential Nomination Campaigns, in FINANCING THE 2004 ELECTION, at $96-$ 97, 115-17 (David B. Magleby, Anthony Corrado \& Kelly D. Patterson, eds., Brookings Inst. 2006).

${ }^{46}$ Green \& Kingsbury, supra note 37 , at 89.

472008 Republican presidential primaries, WIKIPEDIA (last visited May 22, 2019), https://en.wikipedia.org/wiki/2008 Republican Party presidential primaries.
} 
The law's limit on total pre-nomination spending poses other problems. One is the so-called "bridge period." With the candidates furiously spending in the crucial early contests, a winning candidate is likely to hit the spending limit - and be barred from further campaign expenditures -- months before his or her party's national convention. This is essentially what happened to Bob Dole in 1996. Pushed by the intense spending by his privately-funded (and largely self-funded) primary opponent Steve Forbes, Dole had "to spend almost the legal limit during the primaries, leaving him legally unable to raise and spend money from late March until the convention in July." 48 This left Dole vulnerable to an intensive negative advertising campaign in the March-July period by his general election opponent, President Bill Clinton, ${ }^{49}$ who, running unopposed for re-nomination, had accumulated a substantial war chest that included more than $\$ 13$ million in matching funds. ${ }^{50}$ Dole's inability to spend during this bridge period between winning the primaries and being formally nominated at the national convention is one of the factors that led George W. Bush to opt out of public funding in $2000,{ }^{51}$ and forced John Kerry to make a similar decision in 2004.

Of course, not every nomination fight is settled early enough to create a bridge period problem. The nomination battles between Barack Obama and Hillary Clinton in 2008 and between Hillary Clinton and Bernie Sanders in 2016 truly went the distance, with hotly contested primaries and caucuses happening as late as June. There is no way Clinton and Sanders could have competed as long and as intensely as they did under an aggregate primary spending ceiling of less than $\$ 50$ million. Indeed, Sanders spent nearly five times that amount, and Clinton more than ten times the primary spending limit. ${ }^{52}$ On the Republican side, Donald Trump, Ted Cruz, Ben Carson, and Marco Rubio all spent

\footnotetext{
${ }^{48}$ Wesley Joe \& Clyde Wilcox, Financing the 1996 Presidential Nominations: The Last Regulated Campaign?, in FINANCING THE 1996 ELECTION 57 (John C. Green, ed., M.E. Sharpe 1999).

${ }^{49} / d$. at 58-59.

${ }^{50} \mathrm{CFI} 2018$, supra note 22, at 26 (Table 1-1).

${ }^{51}$ See John C. Green \& Nathan S. Bigelow, The 2000 Presidential Nominations: The Costs of Innovation, in FINANCING THE 2000 ELECTION 58 (David B. Magleby, ed., Brookings Inst. Press 2002).

52 Presidential Table 2: Presidential Pre-nomination Campaign Disbursements through December 31, 2016, FEDERAL ELECTION COMMISSION (April 7, 2017), https://transition.fec.gov/press/summaries/2016/tables/presidential/PresCand2 2016 24m.pdf.
} 
above the public funding spending limit, ${ }^{53}$ even though both Carson and Rubio had withdrawn from the race by early March.

Contemporary nomination contests simply cost far too much for candidates to be able to abide by the aggregate primary spending limit. With the matching fund payments statutorily capped at half the spending limit, the program provides far too little money to enable a candidate to fund the kind of campaign needed to win a nomination. As one leading campaign finance scholar pointed out a decade ago, "the cost of running has far outpaced the amount a candidate is allowed to spend." ${ }^{44}$

The other side of the coin is that it has become far easier for candidates to obtain private funds or to benefit from the spending of wealthy supporters. One not fullyappreciated consequence of the McCain-Feingold law (formally the Bipartisan Campaign Reform Act or "BCRA") is that in exchange for placing limits on political party soft money, the law doubled the contribution limits for private donations, and then indexed them for inflation. In other words, the cap on individual contributions, which had been $\$ 1,000$ per donor per election from 1976 through 2000, jumped to $\$ 2,000$ for the 2004 election, and has been set at $\$ 2,800$ for the 2020 election. However, the law increased neither the size of the contribution that could be matched with public funds nor the match ratio. As a result, private financing has become far more attractive relative to public funding.

Candidates also have become more adept at raising large amounts of private contributions. George W. Bush in 2000 demonstrated what the aggressive use of bundlers - individuals who commit to raising the maximum amount of individual donations from a large number of friends and associates - can accomplish. Bush recruited 226 "Pioneers" who each raised $\$ 100,000$ or more from donors who gave the then-maximum of $\$ 1,000$ per person. These bundlers alone accounted for a quarter of Bush's prenomination funds. ${ }^{55}$ Bush did even better in 2004, with two tiers of bundlers - Rangers who brought in $\$ 200,000$ or more, as well the $\$ 100,000$ Pioneers - raising $\$ 77$ million or

\footnotetext{
53 Id.

${ }^{54}$ David B. Magleby, Adaptation and Innovation in the Financing of the 2008 Elections, in FINANCING THE 2008 EleCtION: Assessing Reform 11 (David B. Magleby \& Anthony Corrado eds., Brookings Inst. Press 2011).

${ }^{55}$ See Green \& Bigelow, supra note 51, at 59-60.
} 
$30 \%$ of his total donations. ${ }^{56}$ Obama, Clinton, and McCain in $2008,{ }^{57}$ and Obama and Romney in 2012, also benefited significantly from fundraising by bundlers. ${ }^{58}$

The numbers just cited referred only to contributions collected by a candidate's official campaign committee. Candidates have other means of benefiting from large private donations. A prospective presidential candidate may defer entering the race and engage in a protracted "testing the waters" period, using a leadership PAC, a supportive albeit nominally independent political committee, or a friendly social welfare organization to pay for travel, public appearances, fundraising, political research, polling, and generally laying the groundwork for a campaign. ${ }^{59} \mathrm{~A}$ leadership PAC is a political action committee established or controlled by a candidate that is supposed to be used to support the campaigns of other candidates but can be used to cover some of the expenses of the candidate who controls the PAC. A donor can give up to $\$ 5,000$ per year to a leadership PAC - including non-election years -- which is considerably higher than the cap on donations to the candidate's campaign committee, and, of course, donors can give to both. As a leading study of the "testing the waters" provision found, "[h]istorically, leadership PACs have been very popular vehicles for federal officeholders testing the waters of a presidential campaign." 60

Outside groups, such as 527 organizations and 501(c)(4) organizations have played an important role in funneling big money into nomination campaigns at least since the 2000 election. ${ }^{61}$ Both types of organizations take their names from provisions of the Internal Revenue Code that exempt their income from taxation. 527s are dedicated to political activities; they can accept unlimited contributions and engage in unlimited independent spending, but they are subject to disclosure requirements. 501(c)(4)'s are supposed to be primarily non-electoral, but can engage in some election-related activities.

\footnotetext{
56 See Green, supra note 45, at 104.

57 See Green \& Kingsbury, supra note 37, at 98, 101.

${ }^{58}$ See John C. Green, Michael E. Kohler \& lan P. Schwarber, Financing the 2012 Presidential Nominating Contests, in FinANCING THe 2012 Election 90, 92 (David B. Magleby, ed., Brookings Inst. Press 2014).

59 See generally Paul Ryan, "Testing the Waters" or Diving Right In? How Candidates Bend and Break Campaign Finance Laws in Presidential Campaigns, COMMON CAUSE (January 2019), https://www.commoncause.org/wpcontent/uploads/2019/01/TestingtheWatersFINAL.pdf.

60 ld. at 13.

${ }^{61}$ See Green \& Bigelow, supra note 51, at 56-58.
} 
However, even their technically non-electoral spending may focus on issues that can affect elections. They can accept unlimited contributions and make unlimited expenditures - subject to the requirement that their expenditures are primarily nonelectoral - but they are not required to disclose their donors. Initially, most of the spending by these outside groups occurred in the so-called bridge period and was aimed either at helping the presumptive nominee of the party that the outside group supported or attacking the presumptive nominee of the other party; ${ }^{62}$ in 2008 , however, outside money was also a factor in the internecine Democratic struggle between Obama and Clinton. ${ }^{63}$

In 2012, the role of outside money in nomination campaigns took a quantum leap with the emergence of the Super PAC. In 2010, the U. S. Court of Appeals for the District of Columbia Circuit held that donations to political committees that engage only in independent spending - that is, spending that is not coordinated with any candidate cannot be limited. 64 With the Supreme Court having previously held that such independent spending could not be limited, the D.C. Circuit decision - soon followed by other courts of appeals ${ }^{65}$ - meant that independent-expenditure-only groups could both take and spend money to expressly support or oppose candidates without limits. That is what makes them "super." The Federal Election Commission subsequently determined that even a group that makes donations to candidates can become "super" if it creates a segregated account that makes only independent expenditures; it can then accept unlimited donations to that account. ${ }^{66}$

In 2012, virtually every major candidate had a supportive Super PAC working for him or her. Typically established and run by operatives who had previously been on the candidate's government or campaign staff, the fundraising of these Super PACs made it clear that the contributions they received would be used to advance the political fortunes of that candidate. Indeed, candidates were free to fundraise for their supportive Super PACs, and did so. Super PACs were crucial to the campaigns of many of the 2012

\footnotetext{
62 See, e.g., Green, supra note 45, at 108-11;

63 See Green \& Kingsbury, supra note 37, at 102-06.

${ }^{64}$ SpeechNow.org v. FEC, 599 F.3d 686 (D.C. Cir. 2010).

${ }^{65}$ See generally Richard Briffault, Super PACs, 96 MINN. L. REV. 1644, 1663-65 (2012).

${ }^{66} / d$. at $1665-72$.
} 
Republican contenders, particularly Mitt Romney, Newt Gingrich, Rick Santorum, Jon Huntsman, and Rick Perry. ${ }^{67}$ Indeed, Newt Gingrich's affiliated Super PAC raised more money than his official campaign committee. ${ }^{68}$ And these Super PACs were funded by very large contributions: The vast majority of the contributions to the Obama, Romney, Gingrich, Santorum, Huntsman and Perry Super PACs came in amounts of $\$ 50,000$ or more. ${ }^{69}$

Super PACs were also major players in 2016. Jeb Bush's Super PAC raised a primary season record $\$ 121.1$ million dollars - or nearly four times the sum donated to his campaign committee. ${ }^{70}$ The sum is particularly striking as Bush effectively withdrew from the race after coming in fourth in the South Carolina primary in late February. The Super PACs supporting Marco Rubio, Scott Walker, Chris Christie, Carly Fiorina, Rick Perry, Bobby Jindal, and George Pataki all raised more money than did the formal campaign committees of these candidates, and the receipts of the Super PACs supporting Ted Cruz and John Kasich closely approached the volume of donations to those candidates' official committees. ${ }^{71}$ On the Democratic side, although there was no Super PAC supporting Bernie Sanders, the one supporting Hillary Clinton raised \$106.4 million, or more than a quarter of the aggregate of what her campaign committee and the Super PAC collected. ${ }^{72}$

Of course, not all of the dramatic expansion in private money funding of presidential nomination campaigns over the past two decades has come from large donations. The last several presidential nominating contests have witnessed a remarkable surge in the number of low-dollar donors. Federal law requires candidates to obtain the name, address and other information from any donor of more than \$200. Donors who give $\$ 200$ or less are known as "unitemized donors." Due in significant part to the growing and increasingly sophisticated use of the Internet for fundraising, campaigns in the twenty-first century have raised unprecedented amounts from

\footnotetext{
${ }^{67}$ See Green, Kohler and Schwarber, supra note 58, at 97-101.

${ }^{68}$ See MALBIN \& GLAVIN, supra note 22, at 29 (Table 1-3).

${ }^{69}$ See Green, Kohler and Schwarber, supra note 58, at 98.

${ }^{70}$ See MALBIN \& GLAVIN, supra note 22, at 29 (Table 1-3).

${ }^{71} / d$.

$72 / d$.
} 
unitemized donors. John McCain's 2000 campaign was the first to turn to the Internet; Howard Dean in 2004 was the first to rely primarily on the Internet, and to forego public funds while so doing; and Barack Obama was the first successful candidate to make significant use of the Internet to raise low-dollar donations. Although Internet fundraising requires a substantial start-up investment in personnel, equipment infrastructure, data collection, and database maintenance, once underway it is a relatively cheap way of reaching large numbers of potential small donors and is certainly far more cost-effective than earlier fundraising targeted at small donors such as direct mail. About $30 \%$ of the funds Obama received in the 2008 primary season came from unitemized donors. Although Howard Dean in 2004 received an even higher percentage of his funds from small donors (38\%), and Rand Paul in the 2008 Republican primaries received an even higher fraction (39\%), Obama obtained an impressive $\$ 122$ million in small donations ${ }^{73}$ - nearly triple what he could have obtained in public funds. Obama raised even more in small donations in 2012 -- $\$ 147$ million - while the campaign committees of most of the Republican also-rans in 2012 - Rand Paul, Newt Gingrich, Rick Santorum, Herman Cain, and Michelle Bachman - were also heavily smalldonor funded, although given their limited fundraising success they might have been better off participating in the public funding system. ${ }^{74}$

Small donations were also a big factor in 2016. Bernie Sanders was able to go the distance against Hillary Clinton, campaigning until June, with $44 \%$ of his funds (almost $\$ 100$ million) coming from unitemized donors. Even one-quarter of Clinton's funds (almost $\$ 64$ million) came from such low-dollar donors. On the Republican side, a third or more of the value of individual contributions to the Donald Trump, Ben Carson, Rand Paul, Carly Fiorina, Scott Walker, and Mike Huckabee campaigns came from low-dollar donors, although the aggregate amounts were relative small, as these campaigns either raised relatively little money (Paul, Fiorina, Walker, Huckabee) or, in Trump's case, relied more on self-funding than donors. ${ }^{75}$

\footnotetext{
${ }^{73}$ See Malbin, supra note 28, at 16.

${ }^{74}$ See Green, Kohler, and Schwarber, supra note 58, at 89, 93.

75 See MALBIN \& GLAVIN, supra note 22, at 29 (Table 1-3) and 31 (Table 1-4A).
} 
Trump's successful campaign for the 2016 Republican nomination is a useful reminder that the amount of money a candidate has or spends is not dispositive of the election's outcome. Three of the candidates Trump defeated - Jeb Bush, Ted Cruz, and Marco Rubio - spent more, or had more spent on their behalf than he did. ${ }^{76}$ Trump, of course, benefited tremendously from his pre-campaign celebrity and the massive amount of free media coverage he received. ${ }^{77}$ And he did give or lend more than $\$ 66$ million to his campaign, which was roughly half of his total pre-nomination receipts. ${ }^{78}$ Indeed, he was roughly $75 \%$ self-funded during the crucial early primary phase of the contest. ${ }^{79} \mathrm{His}$ self-financing was far more than he - or any candidate - could have obtained from public matching funds, or than he would have been allowed to spend in private and matching funds together if he had opted for public funds.

III. Going Forward: Should Public Financing Be Saved, and If So, How?

A. Why Public Funding?

There are reasons to question whether public funding should be re-established. A primary goal of public financing is to reduce barriers to entry and thereby make elections more competitive by making it easier for candidates to raise the money necessary to compete. Yet, the recent privately-funded presidential nomination contests have been marked by intensive competition. In 2012, there were nearly a dozen Republican candidates who contested one or more primaries. In 2016, there were so many Republican candidates that they had to be divided into two groups for the pre-primary debates. There were a dozen who contested at least one primary, and eight who raised more than $\$ 10$ million in individual contributions (not counting their supportive Super PACs). ${ }^{80}$ On the Democratic side, although the initial 2016 field of six quickly dropped to two, the Clinton-Sanders race was hotly and closely contested throughout the entire primary season. Moreover, as of late spring 2019, there are a record number of

\footnotetext{
76 Id. at 8.

77 See, e.g., Robin Kolodny, The Presidential Nominating Process, Campaign Money, and Popular Love, 53 Soc. 487 , 490 (2016).

78 Presidential Table 1: Presidential Pre-Nomination Campaign Receipts Through December 31, 2016, supra note 39.

${ }^{79}$ See Kolodny, supra note 77, at 489.

${ }^{80}$ Presidential Table 1: Presidential Pre-Nomination Campaign Receipts Through December 31, 2016 , supra note 39.
} 
candidates for the 2020 Democratic nomination -- nearly two dozen. There has been no lack of competition for the nominations of the major parties when they do not have incumbents seeking reelection.

A second major justification for public financing is to democratize campaign finance by reducing the impact of large and powerful donors and increasing the role of ordinary voters. Again, as already noted, elections over the last two decades have been marked by a striking increase in the number of donors and, especially, in the role of low-dollar donors. More than 784,000 people made itemized donations - that is, donations of more than $\$ 200$-- to contenders for presidential nominations in 2007-08. Although that number dropped to 505,000 in 2012 (when there was no Democratic contest, although President Obama still received contributions), it returned to almost 735,000 in 2016. ${ }^{81}$ Although the precise number of unitemized donors (giving $\$ 200$ and under) is not recorded, they accounted for roughly $24 \%$ of the value of individual donations to the candidates of both parties in 2008; $25 \%$ of the value of individual donations to the Republican candidates in 2012; and $33 \%$ of the individual donations to the candidates of both parties in $2016 .{ }^{82}$ As previously noted, Bernie Sanders received $44 \%$ of his contributions from low-dollar donors. For Sanders, at least, participation in the public funding system would have reduced his ability to raise small donations and would have capped the ability of small donors to participate in his campaign. Moreover, in the opening months of the 2019-20 campaign, many of the Democratic contenders have emphasized the importance of small donors to their campaign or have asserted that they will not turn to lobbyists, interest groups, or Super PACs for support. The Democratic National Committee has also determined that the ability to raise contributions from a large number of donors will be one of the criteria for eligibility to participate in candidate debates. ${ }^{83}$

\footnotetext{
${ }^{81}$ See MALBIN \& GLAVIN, supra note 22, at 31-33 (Tables 1-4A to 1-4C).

82 Id.

${ }^{83}$ See, e.g., Shane Goldmacher, 2020 Democrats Face a Vexing Issue: Big Money from the Rich, N.Y. TIMES, Dec. 11, 2018, https://www.nytimes.com/2018/12/11/us/politics/democrats-2020-super-pac.html; Peter Overby, Democratic Hopefuls Compete to Spurn Establishment Cash, NPR, Feb. 2, 2019, https://www.npr.org/2019/02/02/690156001/democratic-presidential-hopefuls-compete-to-spurn-establishmentcash; Kate Ackley, Small-dollar donors could hold the balance in 2020, Roll CALL, Mar. 15, 2019, https://www.rollcall.com/news/congress/small-dollar-donors-2020-democrats-president-money; Shane Goldmacher, Inside Kamala Harris's Small-Dollar Donor Fund-Raising Operation, N.Y. TIMES, Mar. 26, 2019,
} 
Despite these developments, the traditional arguments for public financing, as articulated by Joe Biden in 1974 - and Theodore Roosevelt in 1907 - still apply to the presidential nomination contests. First, limited access to funds may still operate to limit the ability of candidates to compete. In 2016, there was no incumbent in the Democratic contest, but the six declared candidates quickly dropped to two as none other than Clinton and Sanders were able to raise the necessary funds. Similarly, in the 2012 Republican contest, lack of funds drove a number of contenders out of the race early, and crippled the ability of Romney's principal rivals - Gingrich and Santorum - to compete. ${ }^{84}$ It is less clear what role money played in the 2016 Republican race, in which Trump benefited enormously from free media and a number of his opponents, particularly Bush, Cruz, and Rubio were very well-funded. Nonetheless, several of the candidates in that large field, such as Christie and Huckabee, clearly lacked the funds necessary to mount sustained campaigns. ${ }^{85}$ To be sure, it's not clear the current public funding system could have done much for these candidates. Democrat Martin O'Malley did participate in the public funding program in 2016, much as Joe Biden, Christopher Dodd, and John Edwards did in 2008, and all were out of the running early in the primary season. The quality of the candidates and the dynamic of the particular election matter as much as the financing system. But a lack of adequate candidate funding tends to constrain the choices available to voters.

Moreover, while the volume of small donations has grown tremendously since the turn of the century, the volume of very large donations has also grown significantly. In 2008 , individuals who each donated $\$ 1,000$ or more to a presidential nomination campaign collectively provided candidates with nearly $\$ 500$ million and accounted for more than half of the dollar value of all donations to candidates in each party's contest. For all of his success with small donors, Barack Obama received $44 \%$ of his individual

\footnotetext{
https://www.nytimes.com/2019/03/26/us/politics/kamala-harris-fundraising.html; Alex Gangitano, Opposition to PACs puts 2020 Democrats in a bind, THE HILL, April 3, 20-19, https://thehill.com/homenews/campaign/437063opposition-to-pacs-puts-2020-democrats-in-a-bind, Carrie Levine, Why Democrats are Falling Over Themselves to Find Small-Dollar Donors, FIVETHIRTYEIGHT, Apr. 17, 2109, https://fivethirtyeight.com/features/why-democrats-arefalling-over-themselves-to-find-small-dollar-donors/; Elena Schneider \& Theodoric Meyer, Buttigieg Renounces Lobbyist Donations, Refunding Over \$30,000, PoLITICO, Apr. 26, 2019, https://www.politico.com/story/2019/04/26/buttigieg-lobbyist-donations-2020-1291202.

${ }^{84}$ See Green, Kohler \& Schwarber, supra note 58, at 103-05.

${ }^{85}$ See MALBIN \& GLAVIN, supra note 22, at 29 (Table 3).
} 
primary campaign donations from $\$ 1,000+$ donors, and John McCain received an even more significant $71 \%$ of his individual primary contributions from $\$ 1,000+$ donors. Indeed, $27 \%$ of Obama's donations ( $\$ 87.3$ million) and $49 \%$ of McCain's donations ( $\$ 60.8$ million) came from individuals who "maxed out" - that is, they gave the maximum legally permissible amount. Obama's receipts from maxed-out donations was almost as large as what he obtained from unitemized low-dollar donors. ${ }^{86}$ Moreover, as Michael Malbin has pointed out, the very large donations that Obama received during the so-called "invisible primary" period - that is, the first three quarters of 2007 , long before any actual primary votes were cast - were crucial in establishing him as a serious candidate. His small donations surged later, only as he began to win primaries. ${ }^{87}$

Large donors were prominent again in 2012. On the Republican side, 56\% of the value of individual donations came from individuals who gave $\$ 1,000$ or more, with $40 \%$ coming from maxed-out donors who gave $\$ 2,500$ each. The nomination winner Mitt Romney actually obtained $55 \%$ of his individual contributions from maxed-out donors. ${ }^{88}$ The significance of large donors is even greater once Super PAC funds are taken into account. This makes sense, as an important reason an individual may give to a Super PAC is that he or she has maxed out on the direct contribution to the candidate. Large donors - actually, very large donors, using a $\$ 50,000$ minimum contribution threshold provided an average of $82 \%$ of nomination campaign Super PAC contributions, including $87 \%$ of the contributions to the Romney-, Santorum-, and Perry-linked Super PACs, $88 \%$ of the Huntsman-supporting Super PAC, and $99 \%$ of the pro-Gingrich Super PAC. On the Democratic side, $91 \%$ of the funds contributed to the Obama-affiliated Super PAC came from $\$ 50,000+$ donors. ${ }^{89}$

Similarly, in 2016, large $(\$ 1,000+)$ donors accounted for $55 \%$ of Hillary Clinton's pre-nomination contributions; $40 \%$ came from maxed-out donors. On the Republican side, the candidates received on average $41 \%$ of their individual contributions from large donors and $25 \%$ from maxed-out donors, and that takes into account Donald Trump, who

\footnotetext{
${ }^{86}$ See MALBIN \& GLAVIN, supra note 22 , at 33 (Table $1-4 C$ ).

87 See Malbin, supra note 28 , at 10-15.

${ }^{88}$ See MALBIN \& GLAVIN, supra note 22, at 32 (Table 1-4B).

${ }^{89}$ See Green, Kohler \& Schwarber, supra note 58, at 91-101.
} 
received a below-average share of his contributions from large donors. A number of the other major contenders - including Rubio, Bush, and Kasich - received between 60\% and $87 \%$ of their funds from large donors, and $36 \%$ to $72 \%$ from maxed-out donors. ${ }^{90}$ And, again, many of the candidates - Bush, Clinton, Rubio, and Cruz in particular received massive support from Super PACs, which are financed almost entirely by very large donors. ${ }^{91}$ Large donors often hold views on economic or social issues that diverge from those of average party voters, ${ }^{92}$ so that candidate - and, ultimately, officeholder -dependence on large donors can skew party policies and government actions away from the preferences of the voters.

In short, despite the surge in the number of donors, and especially of low-dollar donors, in recent presidential elections, the impact of the very wealthy may actually be greater than ever. Looking at federal elections in the aggregate - that is, congressional and presidential elections together - one study found that although in the 2000 election cycle just 73,926 individuals accounted for half of all donations, in 2016, a mere 15,810 individuals provided half of all campaign money. ${ }^{93}$ The longstanding goals of public financing - promoting competition by enabling serious candidates to obtain the funds they need to sustain their campaigns, reducing the dependence of candidates (and future officeholders) on large donors, and reducing the disproportionate impact of the wealthy on public policy ${ }^{94}$ - remain unmet by our twenty-first century private nomination campaign finance system. But given the unhappy experience with the current public financing system, can a system be created that accomplishes public funding's goals?

B. The State and Local Public Financing Experience

\footnotetext{
90 See MALBIN \& GLAVIN, supra note 22, at 31 (Table 1-4B).

91 Id. at 29 (Table 3).

92 See, e.g., David Broockman \& Neil Malhotra, What Do Donors Want? Heterogeneity by Party and Policy Domain (Research Note), , Stanford Graduate School of Business Working Papers, Working Paper No. 3757 (Nov. 30, 2018), https://www.gsb.stanford.edu/faculty-research/working-papers/what-do-donors-want-heterogeneity-partypolicy-domain-research-note.

${ }^{93}$ Campaign Finance in the United States: Assessing an Era of Fundamental Change, BIPARTISAN POLICY CENTER, at 2223 (January 2018), https://bipartisanpolicy.org/wp-content/uploads/2018/01/BPC-Democracy-Campaign-Financein-the-United-States.pdf.

${ }^{94}$ For further development of the arguments for public funding, see Briffault, supra note 3, at 117-120.
} 
Even as the federal presidential public financing system has gone into eclipse, states and local governments have created new programs that have had some success in advancing public funding's goals. Currently, at least fourteen states provide some form of public financing option for campaigns, ${ }^{95}$ and another dozen local governments - most prominently New York City, Los Angeles, and Seattle - have implemented or are in the process of implementing some system of public funding for candidates. ${ }^{96}$ These programs take a variety of forms, but three patterns dominate: (i) "clean money" programs that provide a qualifying candidate with a grant intended to fully fund the candidate's campaign; (ii) matching funds programs that, like the current presidential primary system, provide public funds that match small donations but that unlike the presidential system provide funds that are a multiple of the matched small donation; and (iii) voucher programs, under which voters are given vouchers that have a certain value, which they can donate to candidates, who then redeem the vouchers for public funds. ${ }^{97}$

A number of these programs have significant track records. The "clean elections" systems in Arizona, Connecticut, and Maine have been in place for several election cycles - Maine's program was adopted in 1996, Arizona's in 1998, and Connecticut's in 2006 -and have been credited with increasing the competitiveness of elections, increasing the number of candidates able to run for office, diversifying the candidate pool, expanding voter participation in the campaign finance process, and reducing the burdens of fundraising. ${ }^{98}$ New York City's multiple-match system has also been praised for similarly expanding the number and diversity of candidates, increasing electoral competition, and, especially, broadening and diversifying the donor pool. New York's experience has also

\footnotetext{
${ }^{95}$ Overview of State Laws on Public Financing, NAT'L Conf. State LegisLatures (last visited May 22, 2019), http://www.ncsl.org/research/elections-and-campaigns/public-financing-of-campaigns-overview.aspx.

${ }^{96}$ See, e.g., Michael J. Malbin \& Michael Parrott, Small Donor Empowerment Depends on the Details: Comparing Matching Fund Programs in New York and Los Angeles, 15 THE FORUM 219, 220 (2017); The Case for Small Donor Public Financing in New York State, BRENNAN CENTER FOR JUSTICE, at 12-13 (Feb. 26, 2019), https://www.brennancenter.org/sites/default/files/publications/CaseforPublicFinancingNY 0.pdf.

${ }^{97}$ See generally Briffault, supra note 3 , at 107-10.

${ }^{98}$ See, e.g., J. Mijin Cha \& Miles Rapoport, Fresh Start: The Impact of Public Campaign Financing in Connecticut, DeMOS (2013), https://www.demos.org/sites/default/files/publications/FreshStart PublicFinancingCT 0.pdf; GAO, Campaign Finance Reform: Experiences of Two States that Offered Full Public Funding for Political Candidates, U.S. Government Accountability Office, GAO Publication No. GAO-10-390 (May 28, 2010), https://www.gao.gov/assets/310/305079.pdf; Neil Malhotra, The Impact of Public Financing on Electoral Competition: Evidence from Arizona and Maine, 8 ST. PoL. \& PoL’y Q. 263 (2008).
} 
shown the significance of the match rate. Over nearly three decades, New York City has increased the match rate from 1-to-1 to 2-to-1 then 3-to-1, 4-to-1, and in the three most recent general elections 6-to-1, while lowering the maximum matched contribution from $\$ 1,000$ to $\$ 250$ and finally to $\$ 175 .{ }^{99}$ In future elections, the match rate will rise to 8-to-1, and the maximum matchable amount will go back to $\$ 250$. These changes have increased candidate participation in the program, while diversifying the donor pool. In the most recent New York City elections in $2017,84 \%$ of candidates in the primaries participated. The program enjoyed a high level of support, and the participating candidates won the three city-wide elected positions, four of the five borough presidencies, and 36 of 51 City Council seats. Moreover, the program succeeded in stimulating low-dollar contributions for participating candidates, and in generating contributions from neighborhoods around the city. ${ }^{100}$

So far, only one jurisdiction in the United States has adopted a voucher program - Seattle. Under the program, each Seattle resident is eligible to receive four \$25 "democracy vouchers," which the resident may contribute to qualifying candidates, who may then cash them in with Seattle's elections agency for public funds. ${ }^{101}$ The program was adopted by the city's voters in 2015, and first used in 2017 for two city-wide at-large council races and in the election for city attorney. The winning candidates in all three races qualified for vouchers, as did the principal runners-up in the council races. And voucher proceeds accounted for a majority of total individual contributions in the council elections and a majority of the contributions to the winner of the city attorney race. According to the Seattle Ethics and Elections Commission, the introduction of vouchers increased the number of residents contributing, lowered the size of the average contribution, increased the percentage of contributions coming from within Seattle, and spread the sources of contributions "more equitably" across the city's neighborhoods. ${ }^{102}$

\footnotetext{
${ }^{99}$ Malbin \& Parrott, supra note 96, at 224-25.

100 See New York City Campaign Finance Board, Keeping Democracy Strong: New York City's Campaign Finance Program IN THE 2017 CITYWIDE ELeCTIONS, at 1, 45, 52-57 (2018), https://www.nyccfb.info/pdf/2017 Post-

Election Report_2.pdf.

${ }^{101}$ See Democracy Voucher Program, SeAtTle.gov (last visited May 22, 2019), http://www.seattle.gov/democracyvoucher/i-am-a-seattle-resident.

1022017 Election Report, SEATTLE ETHICS \& ELECTIONS COMMISSION (March 9, 2018), http://www.seattle.gov/ethics/meetings/2018-03-09/item4.pdf.
} 
Each type of public funding program has its own strengths and weaknesses. Small donor multi-match and voucher programs are better than clean money's flat grant at increasing public participation in the campaign finance process. On the other hand, clean money is better at freeing candidates from the burdens of fundraising. Voucher programs enable each resident to determine which candidates get his or her public funds, but that is also true of small-donor matching. With vouchers, there is considerable uncertainty as to how many residents will actually donate their vouchers and when they will do so. It appears that in the first Seattle election in which vouchers were used, only about $4 \%$ were contributed to an office-seeker and most were returned just before the election, which could limit their usefulness to candidates. ${ }^{103}$ It may be that the differences across jurisdictions in the specific provisions of a category of program are as important as the differences in the types of programs. ${ }^{104}$ But studies of these systems do indicate that a properly crafted public financing program can draw the participation of viable candidates, provide them with sufficient funding, and increase both the competitiveness of elections and the funding role of ordinary voters.

\section{Toward A Better Financing System}

The presidential nomination public funding program created in 1974 played an important role in sustaining competition and reducing dependence on large donors for more than two decades, but it is effectively moribund. There have been calls for its outright abolition. ${ }^{105}$ Instead, it should be restored to life. But any new system must draw on the lessons learned from the collapse of the old, we well as from the experiences of the many state and local public funding programs. Most importantly, the campaign finance system must be attuned to the structure of the nomination process and the concerns of the candidates who participate in it.

\footnotetext{
103 See Democracy Voucher Program: Biennial Report 2017, SEATTLE ETHICS \& ELECTIONS COMmISSION, at 14, https://www.seattle.gov/Documents/Departments/EthicsElections/DemocracyVoucher/Final\%20\%20Biennial\%20report\%20-\%2003 15 2018.pdf.

104 See Malbin \& Parrott, supra note 96, at 224-45.

105 R. Sam Garrett, Proposals to Eliminate the Public Financing of Presidential Campaigns, Cong. Res. Serv., Report No. R41604 (Feb. 7, 2017), https://fas.org/sgp/crs/misc/R41604.pdf.
} 
First, public funds must be provided on a timely basis. The provision of the 1974 law delaying the first payment until the start of the election year is entirely out-of-step with the calendar of today's nomination process. Payments should be available throughout the year preceding the year of the election. Second, and relatedly, the state-specific spending limits make no sense in what has become essentially a national election in which the importance of the early states is often far out of proportion to their voting population. Third, the system must provide enough money to sustain a viable campaign so that it is more attractive to serious candidates than the private funding route. It is hard to say exactly what that amount should be, but it is surely far more than the \$24 million funding cap that applied in 2016. It is almost certainly more than $\$ 100$ million, and $\$ 200$ million could be appropriate. Of course, not every candidate should receive that much public money. The amount any candidate receives should reflect her seriousness as a candidate, which may be measured by her success in grass-roots fundraising or the votes she obtains in primaries and caucuses. The law could also certainly raise the initial conditions for eligibility above the minimal fundraising threshold set in 1974, and index that level to inflation thereafter.

Finally, candidates should not be required to accept spending limits as a condition for public funds. Spending limits are counterproductive. As long as candidates with access to their own personal wealth or the fundraising of high-dollar bundlers are free to rely on private funding without limits, and as long as independent groups are also free to raise and spend money without limits - and current constitutional doctrine indicates that these conditions are likely to obtain for the foreseeable future - spending limits will disadvantage publicly-funded candidates and are likely to discourage serious candidates who can raise substantial private funds from participating in a public funding program. Public funding can achieve its goals of increasing electoral competitiveness and reducing the role of large donors without spending limits.

That does not mean that public funding should be unlimited. A workable system could include a sizeable public grant - allotted on a small-donation-multiple-match basis - up to a maximum amount, with candidates who reach that ceiling free to raise and spend additional private contributions, perhaps limited to low-dollar donations. Such a program 
would lower barriers to entry for candidates without access to large donors and provide incentives to reaching out widely to small donors, without handicapping participating candidates' ability to compete against their privately funded opponents.

H.R. 1 - the "For the People Act of 2019" - passed by the House of Representatives in March 2019 provides an appropriate model. Proposed to take effect with the 2028 presidential election, it would provide qualifying candidates a 6-to-1 match for the first $\$ 200$ of contributions received from any individual, up to a maximum of $\$ 250$ million, subject to future cost-of-living indexation. There would be no spending limit for publicly-funded candidates; however, the candidate would have to agree to accept no more than $\$ 1,000$ in the aggregate from any donor. H.R. 1 contains many other specific limitations and requirements dealing with the financing of nomination campaigns that would need to be considered, and in any event it is unlikely to be taken up by the Senate or signed by the President any time soon. But it does lay out some of the elements that are critical to a successful public financing program.

As young Senator Biden recognized in 1974, public financing is "not a cure-all for all the ills besetting our present political system." ${ }^{106}$ But a viable public financing program for the presidential nomination process could address the concerns about political inequality and wealth-based barriers to electoral competition that he raised more than four decades ago and that continue to remain troubling features of our political system.

${ }^{106}$ Biden, supra note 1 , at 70. 